\title{
0633. Time-resolved spectroscopy using non- invasive monitoring may detect hapatic ischemia
}

\author{
Y Tomotsugu*, Y Kakihana, K Yamaguchi, M Nakahara, T Futatsuki, J Taniguchi, K Nakamura, N Okayama \\ From ESICM LIVES 2014 \\ Barcelona, Spain. 27 September - 1 October 2014
}

\section{Introduction}

The aim of the present study was to investigate whether the changes in hepatic oxygenation can be detected by time-resolved spectroscopy (TRS) placed on the skin surface above the liver.

\section{Methods}

With approval of the local Hospital Ethics Committee and informed consent, 6 healthy volunteers aged 28.8 years (25-36 years), and 5 patients with chronic renal failure aged 70.6 years (58-81 years) were studied. In 6 healthy volunteers, following the echography, TRS (TRS10, Hamamatsu Photonics K.K., Hamamatsu, Japan) probe consisting of a near-infrared light (at $760 \mathrm{~nm}$, $800 \mathrm{~nm}, 835 \mathrm{~nm}$ ) emitter and a receiver optode, was placed $4 \mathrm{~cm}$ apart on the abdominal skin surface above the liver or apart from the liver at least $10 \mathrm{~cm}$. In 5 patients with chronic renal failure, following the echography, TRS probes were placed $4 \mathrm{~cm}$ apart on the skin surface above the liver during hemodialysis (HD).

\section{Results}

In 6 healthy volunteers, the values of abdominal total hemoglobin concentration ( $\mathrm{tHb}$ ) was significantly higher in the liver area than in the other area $(80.6 \pm 26.81 \mathrm{mM}$ vs $44.6 \pm 23.1 \mathrm{mM}, \mathrm{P}=0.0017$ ), while the value of abdominal $\mathrm{SO}_{2}$ in the liver area was nearly the same as that in the other area $(71.5 \pm 3.6 \%$ vs $73.6 \pm 4.6 \%, \mathrm{P}=0.19)$. The values of mean optical path length and scattering coefficient $\left(\mu^{\prime} \mathrm{s}\right)$ at $800 \mathrm{~nm}$ in the liver area were significantly different from those in the other area $(21.3 \pm 4.9 \mathrm{~cm}$ vs $29.2 \pm 5 \mathrm{~cm}$, $\mathrm{p}=0.0004$, and $7.97 \pm 1.14 \mathrm{~cm}-1 \mathrm{vs} 9.02 \pm 0.51 \mathrm{~cm}-1, \mathrm{P}=0.015$ ). One of 5 patients with chronic renal failure complained of the severe abdominal pain during $\mathrm{HD}$, and the abdominal $\mathrm{SO}_{2}$ was decreasing from $53 \%$ to $22 \%$, but the pain relief

Kagoshima University Hospital, Intensive Care Medicine, Kagoshima University, Japan

(c) 2014 Tomotsugu et al; licensee Springer. This is an Open Access article distributed under the terms of the Creative Commons Attribution License (http://creativecommons.org/licenses/by/2.0), which permits unrestricted use, distribution, and reproduction in any medium, provided the original work is properly cited. occurred following cessation of $\mathrm{HD}$, and $\mathrm{SO}_{2}$ recovered to the baseline.

\section{Conclusions}

Our data suggest that the optical properties of the liver may be measured by the TRS placed on the skin surface, and the hepatic oxygenation may act as a non-invasive monitoring for early detection of intestinal ischemia.

Published: 26 September 2014

doi:10.1186/2197-425X-2-S1-P43

Cite this article as: Tomotsugu et al:: 0633. Time-resolved spectroscopy using non-invasive monitoring may detect hapatic ischemia. Intensive Care Medicine Experimental 2014 2(Suppl 1):P43.

Submit your manuscript to a SpringerOpen ${ }^{\bullet}$ journal and benefit from:

- Convenient online submission

- Rigorous peer review

- Immediate publication on acceptance

- Open access: articles freely available online

- High visibility within the field

Retaining the copyright to your article

Submit your next manuscript at $>$ springeropen.com 